\title{
Historical ethnobotany: an overview of selected studies
}

Taline Cristina da Silva"*, Patrícia Muniz Medeiros², Alejandro Lozano Balcazár', Thiago Antônio de Sousa Araújo ', Analia Pirondo ${ }^{3}$, Maria Franco Trindade Medeiros ${ }^{4}$

\begin{abstract}
Historical Ethnobotany is an area of research responsible for understanding past interrelationships between people and plant using written records and iconography. The literature on this topic is scattered, and many of these studies are not recognised as such; therefore, it is difficult to compile historical ethnobotanical data. Accordingly, this study attempted to draw a general picture of the publications in this field. The Scopus, ISI Web of Knowledge and Scirus databases were used to search for articles with such keywords as "Ethnobotany + History" and "Historical Ethnobotany" among others. After the studies were selected, information was extracted that included the continents addressed and historical ages. Most studies encompassed a time frame that began in the Modern Age (54.7\%), and $46 \%$ of the studies were focused on the American continent. With regard to the nature of the source, $98 \%$ of the studies included written records, and publications that used the documental analysis as a secondary data in their scope of research were among the most frequent types of studies that were found. In respect to iconographic sources, paintings were used in $6 \%$ of the studies. A total of $66 \%$ of the studies involved a species or species group as the study object. Our survey revealed the vast scope of these Historical Ethnobotany studies. We believe that this scientific field has great potential for future development and that its findings will only grow in importance considering the current ethnobotanical debate.
\end{abstract}

Keywords: Ethnobiology, Ethnobotany, historical documents, human populations, literature review, plant use.

\section{INTRODUCTION}

The use of historical documents is of utmost importance for the accession of information that highlights the past relationships between human beings and their environment. Discovering or obtaining information that is found in manuscripts, books or other sources promotes a chronological view of evolving plant uses, for example, on the question of the concepts of diseases and forms of cultivation (Barbera et al. 1992; Pardo-de-Santayana et al. 2006; Zepeda and White 2008; Bussmann and Sharon 2009). The chronological analysis of all disease concepts throughout history can help to clarify our current conceptions. However, extracting, analysing and interpreting these types of data represents a challenge, as it requires itself

1 Laboratory of Applied and Theoretical Ethnobiology, Department of Biology, Area of Botany, Federal Rural University of Pernambuco, Av. Dom Manoel de Medeiros s/n, Dois Irmãos, CEP: 52171-900, Recife, Pernambuco, Brazil. E-mail address: talinecs@hotmail.com

2 Instituto de Ciências Ambientais e Desenvolvimento Sustentável - Universidade Federal da Bahia. Estrada do Barrocão, s/n, Morada Nobre, Barreiras, Bahia, Brazil

3 Instituto de Botánica del Nordeste UNNE-CONICET (Corrientes, Argentina).

4 Universidade Federal de Campina Grande, Campus de Cuité, Centro de Educação e Saúde, Unidade Acadêmica de Educação, Departamento de Ciências Biológicas, Olho D’Água da Bica s/n, CEP: 58175-000, Cuité, Paraíba, Brazil. 
knowledge from different areas, such as History, Anthropology and Biology.

The scientific field that addresses these different aspects and that is responsible for understanding part of these interrelationships by focusing on the dynamics established between humans and plants is called Ethnobotany. Within this field, one of the research approaches concerning the past interrelationships through the use of written records and iconography is known as Historical Ethnobotany (Medeiros et al. 2010). Historical Ethnobotany differs from Paleoethnobotany or Archeobotany by including archaeological records and aims to understand the interrelationships between humans and plants (Ford 1979). Despite having similar subjects of study, the differences between Paleoethnobotany and Historical Ethnobotany are based on methodology. Such research is of great relevance because it aids in the reconstruction of historical facts that guide future studies aimed at novel plant-derived discoveries (Giorgetti and Rodrigues 2007; Burns 2008) to verify changes in vegetation cover and species distribution (Oudijk and Jansen 2000; Smith et al. 2003), to assist in understanding the process of plant species domestication (Raghavan and Baruah 1958; Negbi 1992; Prohens et al. 1996), to show temporal changes in plant use and to describe the history of cultivation and the economic importance of certain plants (Goor 1965; Porterfield 2008).

In addition, it should be noted that this scientific field allows for the reconstruction of cultural identities, from small human groups to large civilizations, through the retrospective review of different historical plant uses, such as food, wood, magical/religious purposes and medicinal and fibre applications (Norton 1981; Leal and Amaya 1991; Bedigian 2004; De Natale et al 2009). There are several articles that have already been published using these approaches. However, the literature on this topic is scattered, and it is therefore difficult to categorize these studies because they are not recognised as Historical Ethnobotanical studies.

Therefore, the present study represents one of the first efforts to compile and classify these studies and aims to outline an overview of selected published articles in this field. Accordingly, the aim of the present study was to compose a general profile of the research related to Historical Ethnobotany and to identify gaps and future perspectives in this field of research.

\section{METHODS}

This study involved the review of published articles that used written records, iconography and/or secondary data to access specific historical aspects of plant resources. Although this study aimed to provide an extensive literature review of how Historical Ethnobotany studies have been presented, it is not intended to be an exhaustive review all of materials on this subject.

To search for articles, were queried the Scopus (www.scopus.com), ISI Web of Knowledge (www. isiknowledge.com) and Scirus (www.scirus. org) databases using the following search terms: "Ethnobotany + History", "Historical Ethnobotany", "Ethnohistory + Plants" and "Ethnobotany + Ancient Documents". To broaden the search criteria, direct surveys were performed on the websites of journals specialising in Ethnobotany (i.e., Economic Botany, Journal of Ethnopharmacology, Journal of Ethnobiology, Journal of Ethnobiology and Ethnomedicine and Ethnobotany Research and Application) using the search term "History". These search criteria yielded both ethnobotanical studies and also related but differentially labelled works; the latter were also included in this review. Studies of an archaeological nature were disregarded because they are classified under Paleoethnobotany (Albuquerque 1997), and studies with archaeological approaches were only included when they employed mixed approaches for archaeological or historical data and documentation. It was not possible to access to the entire wealth of publications on the subject.

After selecting reports for inclusion in our study, we extracted information regarding the following aspects of the select studies: (1) the continents addressed, (2) historical ages, (3) nature of the source, (4) types of sources used, (5) approaches, (6) use categories covered and (7) the existence of a counterpoint to the current literature on the subject. 
Some studies provided information on more than one continent, used more than one source type, involved more than one approach or involved more than one use category. Therefore, the sum of the frequencies of these study aspects could be greater than $100 \%$. Mixed-nature studies, including archaeological and documentary information, were considered by dating the proper historical sources, excluding the dating of archaeological evidence.

The nature of the sources was classified as written or iconographic. The iconographic sources included paintings, illustrations, sculptures, ceramics and other objects. In terms of mediation, the sources were classified as primary when they provided direct information about the object of study without mediation (Dalton and Charnigo 2004), regardless of whether the original records or the transcripts were primary or secondary. The types of primary written sources were classified as official documents (e.g., issued by former government agencies, kingdoms), manuscripts (e.g., codices, written literature, religious books and diaries and writings of travellers, naturalists and historians) and letters (unofficial writing directed to others) and prescriptions (medical or cooking prescriptions). Secondary sources included publications (recent works published in journals or books including historical information).

We used the following three categories for the analysis of the study object (Medeiros et al. 2009): (1) the focus was the analysis of a document source, (2) the focus was the species or species group and (3) the idea was derived from a study subject. Studies conflicting with the current literature were classified when they conformed to at least one of the following two criteria: (1) performing comparisons among the use, trade, cultivation or spread of plants in the past and present; or (2) following up the historical development of the cultivation, use, trade or distribution of a specific plant or a plant group. We did not refine our analysis in relation to the correct botanical nomenclature of the plants found in the works because, as mentioned above, our focus was solely to determine whether plants were the main focus of the research.

\section{RESULTS AND DISCUSSION}

After filtering the relevant works, the search criteria identified 103 studies for inclusion (Table 2). Due to limited journal access or restricted content, the searches yielded a greater amount of recent works compared to past works. In total, 103 articles and reviews published between 1949 and 2012 were considered. Most of the studies occurred over a time frame that began in the Modern age (54.7\%) or Contemporary age (25\%), followed by Antiquity $(21 \%)$ and the Middle Age (7\%). However, $8 \%$ of the studies did not clearly delineate the specific contextual time frame encompassed, providing only such descriptions as "since ancient times" or "long ago". The frequent lack of a specific contextual time frame is attributed to the difficulty in knowing the exact or approximate date of the source and may represent a lack of sufficient attention when dealing with historical data.

A total of $51 \%$ of the studies provided historical information regarding the American continent, whereas $46 \%, 36 \%, 18 \%$ and $6 \%$ of the studies provided information related to Europe, Asia, Africa and Oceania, respectively. Our results indicated that the modern age represents the majority of early records and that the American continent is the main focus of historical ethnobotanical research. This finding can be explained by the following two factors: (1) an abundance of historical records about the colonization of the New World, including letters, diaries and manuscripts of naturalists and travellers who documented the previously unknown richness of flora and fauna of the Americas and their preColumbian applications; and (2) a great interest by researchers to collect historical information on the use of plant resources in the pre-colonial and early colonial periods (Table 2).

One example is a study on the indigenous usage of plants during the Hispanic colonization of Mexico (Zepeda and White 2008). This study was based on the mural paintings by indigenous artists from the convent of the Divine Saviour of Malinalco, which, in addition to illustrating various aspects of Catholic beliefs, also incorporated elements of the local fauna and flora. The plants depicted in the paintings were identified, and their uses were assessed from codices of that period to 
derive information about the pre-Hispanic uses of local plant species.

When comparing the different regions of the American continent, both North and South America exhibited the same percentage of studies, $18.3 \%$ each, whereas Central America exhibited 16\% coverage, despite this continent be much smaller than the others cited. This average of studies developed in Central America could be justified by the fact that the researches made on this geographical region were focused on key-species that are distributed along this area and key-species that have an expressive economic importance for the world, like "vanilla" (see Correll 1953).

Regarding the nature of the sources, $98 \%$ of the studies extrapolated information from written records, which is expected because this type of record is the main form of overall historical research. Indeed, the emergence of writing itself has classically represented a watershed between prehistorical and subsequent historical periods (Rai 2010). Iconographic sources have rarely been used in historical ethnobotanical studies and were found in only $14.0 \%$ of all of the papers analysed and were generally associated with the analysis of written records.

Among the most frequent types of written records were publications that used this kind of documentation as a secondary data in their analysis (and not as original source of informations). The adoption of documentary analysis by the authors of these studies was to achieve a more complete coverage of historical aspects on the topics covered in the survey. Considering the written records used as primary or secondary sources, these included: manuscripts, letters, diaries, prescriptions, old books; beyond official documents from governments, kingdoms or related organisations (Table 1).

Table 1. The main source types found in 103 historical ethnobotanical publications.

\begin{tabular}{cccc}
\hline Source nature & \multicolumn{3}{c}{ Type of source } \\
\hline Writing & $(98 \%)$ & Publications & $(77 \%)$ \\
& & Manuscripts & $(52 \%)$ \\
& & Official documents & $(22.1 \%)$ \\
& & Prescriptions & $(4.7 \%)$ \\
Iconographic & $(12.0 \%)$ & Others & $(3.1 \%)$ \\
& & Paintings & $(5 \%)$ \\
& & Illustrations & $(2.2 \%)$ \\
& & Artefacts & $(1.1 \%)$ \\
& & Others & $(4.4 \%)$ \\
\hline
\end{tabular}

With regard to iconographic sources, paintings were used in $6 \%$ of all studies, with different source forms, including murals, paintings and ceramics; iconographic sources including illustrations and artefacts were less informative (Table 1). Some illustrations of domesticated plants such as wheat and corn observed in the work of Zeven and Brandenburg (1986), important in festivities plants were found, such as grape (Vitis vinifera L.) used for the manufacture of wine and illustrated by people of antiquity (see Goor 1965), medicinal plants as illustrated in a convent wall from Mexico (Zepeda and White 2008) and others. There were also works in which it was not possible to identify the nature of their iconographic sources; these works were therefore included in the "others" category.

Some codices have served as a source for various studies, and such writings represent significant historical significance for their respective countries or regions of origin in terms of a pioneering character or an exemplary compilation.

Among the most used codices as source by these analysed publications, it is highlighted the Florentine Codex (Zepeda and White 2008; 
Terraciano 2010), which represents the most detailed chronicle of pre-Hispanic culture and a large graphic plurality of the Mexican colonial period (Zárate 1997), and De Materia Medica of Dioscorides (Negbi 1992; De Natale et al. 2009; Leonti et al. 2009; Leonti et al. 2010).

No works analysed thus far have used photographs as a data source, whereas photographic records have been commonly used to only illustrate species encompassed by the respective study or to represent sculptures, illustrations and other curios, which are iconographic sources themselves. Perhaps the fact that photographic resources are relatively recent entities compared to other iconographic features has limited their usage in historical ethnobotanical studies. The "Others" category included other types of written and iconographic sources, such as cave paintings, and was present in $6.5 \%$ of all publications.

The paths that the authors use in the design of the survey were mainly in three ways, called by Medeiros (2009) as "species-document", "document-species" and "theme-documentspecies" (Table 2). Sixty-seven percent of all studies were performed on a single species or species group defined as the study object, which was queried to locate historical records regarding the aspects of human relationships with the study object ("species-document" - e.g., uses, harvesting methods). Other topic-specific ("theme-documentspecies" - e.g., poisonous plants) studies either used related records $(17 \%)$ or historical documents (16\%, e.g., recipes or codices) for information about the plants that were studied ("document-species").

Table 2. Main information extracted from 103 publications related to historical ethnobotany.

\begin{tabular}{|c|c|c|c|c|}
\hline REFERENCES & $\begin{array}{c}\text { AGE OF } \\
\text { DOCUMENT }\end{array}$ & $\begin{array}{l}\text { PLACE OF DOCUMENT } \\
\text { ORIGIN }\end{array}$ & $\begin{array}{l}\text { NATURE OFTHE } \\
\text { SOURCE }\end{array}$ & SEARCH PATH \\
\hline $\begin{array}{l}\text { ABRAMS and NOWACKI } \\
2008\end{array}$ & Timeframe unclear & North America & Writing & Document-species \\
\hline ADERKAS 1984 & Modern age & North America & Writing & Species-document \\
\hline ALENCAR ET AL 2010 & Modern age & South America & Writing & Document-species \\
\hline ARGOUNOVA-LOW 2009 & Contemporary age & Asia & Writing & Document-species \\
\hline AUSTIN 2007 & Modern age & $\begin{array}{l}\text { Africa; Central } \\
\text { America; North } \\
\text { America; South } \\
\text { America; Asia; Oceania }\end{array}$ & Writing & Species-document \\
\hline AUSTIN 2008 & Modern age & $\begin{array}{l}\text { Africa; Central } \\
\text { America; South } \\
\text { America; Asia; Europe }\end{array}$ & Writing & Species-document \\
\hline AUSTIN and FELGER 2008 & Modern age & Africa; Asia; Europe & Writing & Species-document \\
\hline BARBERA ET AL 1992 & Modern age & Europe & Writing & Species-document \\
\hline BEDIGIAN 2004 & Antiquity & Africa; Asia & $\begin{array}{l}\text { Writing; } \\
\text { Iconographic }\end{array}$ & Species-document \\
\hline BRANDÃO ET AL 2008 & Modern age & South America & Writing & Document-species \\
\hline BRANDÃO ET AL 2009 & Contemporary age & South America & Writing & Document-species \\
\hline BRENDLER and WYK 2008 & Modern age & Africa; Europe & Writing & Species-document \\
\hline BUCKLES 1995 & Contemporary age & $\begin{array}{l}\text { Central America; North } \\
\text { America }\end{array}$ & Writing & Species-document \\
\hline BURNS 2008 & Contemporary age & Asia & Writing & Species-document \\
\hline BURTON and COX 1998 & Contemporary age & North America & Writing & Species-document \\
\hline $\begin{array}{l}\text { BUSSMAN and SHARON } \\
2009\end{array}$ & Modern age & South America & $\begin{array}{l}\text { Writing; } \\
\text { Iconographic }\end{array}$ & $\begin{array}{l}\text { Theme-document- } \\
\text { species }\end{array}$ \\
\hline CHADWICK ET AL 1993 & Antiquity & Asia & Writing & Species-document \\
\hline
\end{tabular}




\begin{tabular}{|c|c|c|c|c|}
\hline REFERENCES & $\begin{array}{c}\text { AGE OF } \\
\text { DOCUMENT }\end{array}$ & $\begin{array}{l}\text { PLACE OF DOCUMENT } \\
\text { ORIGIN }\end{array}$ & $\begin{array}{l}\text { NATURE OFTHE } \\
\text { SOURCE }\end{array}$ & SEARCH PATH \\
\hline $\begin{array}{l}\text { CHARNEY and BASBOUS } \\
1978\end{array}$ & Antiquity & Asia & $\begin{array}{l}\text { Writing; } \\
\text { Iconographic }\end{array}$ & Species-document \\
\hline COLLINS 1949 & Modern age & South America & Writing & Species-document \\
\hline CORREL 1953 & Modern age & Central America & Writing & Species-document \\
\hline DAFNI ET AL 2005 & Antiquity & Asia & Writing & Species-document \\
\hline DE NATALE ET AL 2009 & Modern age & Europe & Writing & Document-species \\
\hline $\begin{array}{l}\text { DELYSER and KASPER } \\
1994\end{array}$ & Mean age & $\begin{array}{l}\text { North America; Asia; } \\
\text { Europe }\end{array}$ & Writing & Species-document \\
\hline DOVE 1997 & Modern age & Asia & Writing & Species-document \\
\hline EDWARSON 1952 & Mean age & Europe & Writing & Species-document \\
\hline ERWIN 1950 & Modern age & $\begin{array}{l}\text { Central America; South } \\
\text { America; Europe }\end{array}$ & Writing & Species-document \\
\hline FULLING 1953 & Modern age & Central America & Writing & Species-document \\
\hline GENTRY ET AL 1958 & Modern age & Central America & Writing & Species-document \\
\hline $\begin{array}{l}\text { GIORGETTI and } \\
\text { RODRIGUES } 2007\end{array}$ & Modern age & South America & Writing & $\begin{array}{l}\text { Theme-document- } \\
\text { species }\end{array}$ \\
\hline GOOR 1965 & Antiquity & Asia & Writing & Species-document \\
\hline GOOR 1966a & Antiquity & Asia & $\begin{array}{l}\text { Writing; } \\
\text { Iconographic }\end{array}$ & Species-document \\
\hline GOOR 1966b & Antiquity & Asia & $\begin{array}{l}\text { Writing; } \\
\text { Iconographic }\end{array}$ & Species-document \\
\hline GOOR 1967a & Antiquity & Asia & $\begin{array}{l}\text { Writing; } \\
\text { Iconographic }\end{array}$ & Species-document \\
\hline GOOR 1967b & Antiquity & Asia & $\begin{array}{l}\text { Writing; } \\
\text { Iconographic }\end{array}$ & Species-document \\
\hline GUARINO ET AL 2000 & Modern age & Europe & $\begin{array}{l}\text { Writing; } \\
\text { Iconographic }\end{array}$ & Species-document \\
\hline HALLER JR. 1990 & Modern age & $\begin{array}{l}\text { Africa; North America, } \\
\text { Asia; Europe }\end{array}$ & Writing & Species-document \\
\hline HEINRICH ET AL 2006 & Contemporary age & Central America & Writing & $\begin{array}{l}\text { Theme-document- } \\
\text { species }\end{array}$ \\
\hline $\begin{array}{l}\text { HERNANDEZ and GARCIA } \\
1998\end{array}$ & Mean age & Europe & Writing & Document-species \\
\hline HSU 2006 & Antiquity & Asia & Writing & Species-document \\
\hline HU 1967 & Contemporary age & Asia & Writing & Species-document \\
\hline $\begin{array}{l}\text { HYMOWITZ and HARLAN } \\
1983\end{array}$ & Modern age & North America & $\begin{array}{l}\text { Writing; } \\
\text { Iconographic }\end{array}$ & Species-document \\
\hline JOUBERT ET AL 2008 & Contemporary age & Africa & Writing & Species-document \\
\hline KINGSBURY 1961 & $\begin{array}{l}\text { Antiquity; } \\
\text { Contemporary age }\end{array}$ & Europe; North America & Writing & $\begin{array}{l}\text { Theme-document- } \\
\text { species }\end{array}$ \\
\hline KITAGAWA ET AL 2008 & Contemporary age & Asia & Writing & Species-document \\
\hline $\begin{array}{l}\text { KROCHMAL and } \\
\text { GRIERSON } 1961\end{array}$ & Modern age & North America & Writing & Species-document \\
\hline LEAL E AMAYA 1991 & Modern age & South America & Writing & Species-document \\
\hline LEONTI ET AL 2009 & Antiquity & Europe & Writing & Document-species \\
\hline LEONTI ET AL 2010 & Modern age & Europe & Writing & Document-species \\
\hline LOCHER and CURRIE 2010 & Modern age & Europe; Oceania & Writing & $\begin{array}{l}\text { Theme-document- } \\
\text { species }\end{array}$ \\
\hline LUCZAJ 2008 & Contemporary age & Europe & Writing & Document-species \\
\hline LUCZAJ 2009a & Modern age & Europe & Writing & Document-species \\
\hline LUCZAJ 2009b & Modern age & Europe & Writing & Species-document \\
\hline
\end{tabular}




\begin{tabular}{|c|c|c|c|c|}
\hline REFERENCES & $\begin{array}{c}\text { AGE OF } \\
\text { DOCUMENT }\end{array}$ & $\begin{array}{l}\text { PLACE OF DOCUMENT } \\
\text { ORIGIN }\end{array}$ & $\begin{array}{l}\text { NATURE OFTHE } \\
\text { SOURCE }\end{array}$ & SEARCH PATH \\
\hline LUCZAJ 2010a & Contemporary age & Europe & Writing & $\begin{array}{l}\text { Theme-document- } \\
\text { species }\end{array}$ \\
\hline LUCZAJ 2010b & Modern age & Europe & Writing & Document-species \\
\hline LUCZAJ 2010c & Modern age & Europe & Writing & Document-species \\
\hline LUCZAJ 2012 & Modern age & Europe & $\begin{array}{l}\text { Writing; } \\
\text { Iconographic }\end{array}$ & Species-document \\
\hline LUCZAJ ET AL 2012 & Modern age & Europe & Writing & Species-document \\
\hline MARTIN 1970 & Mean age & South America & $\begin{array}{l}\text { Writing; } \\
\text { Iconographic }\end{array}$ & Species-document \\
\hline MEDEIROS ET AL 2010 & Modern age & South America & Writing & Document-species \\
\hline MEDERIOS ET AL 2007 & Contemporary age & South America & Writing & Species-document \\
\hline MERLIN 2000 & Modern age & Oceania & Writing & $\begin{array}{l}\text { Theme-document- } \\
\text { species }\end{array}$ \\
\hline MONACHINO 1954 & Modern age & Asia & Writing & Species-document \\
\hline $\begin{array}{l}\text { MOOLLA and VILJOEN } \\
2008\end{array}$ & Modern age & Africa & Writing & Species-document \\
\hline MULLER ET AL 2010 & Modern age & North America & Writing & Species-document \\
\hline NEGBI 1992 & Antiquity & Africa; Europe & Writing & Species-document \\
\hline NICHOLSON 1958 & Antiquity & Africa & Writing & Species-document \\
\hline NORTON 1979 & Modern age & North America & Writing & Species-document \\
\hline NORTON 1981 & Modern age & North America & Writing & Document-species \\
\hline OUDIJK and JANSEN 2000 & Modern age & Central America & Iconographic & $\begin{array}{l}\text { Theme-document- } \\
\text { species }\end{array}$ \\
\hline PALMER 1985 & Modern age & Europe & Writing & Document-species \\
\hline $\begin{array}{l}\text { PARDO DE SANTANAYA ET } \\
\text { AL } 2006\end{array}$ & Modern age & Europe & Writing & Document-species \\
\hline POLATA and SATIL 2012 & Modern age & Europe & Writing & Species-document \\
\hline POLLIO ET AL 2008 & Antiquity & Europe & Writing & Species-document \\
\hline PORTERFELD 2008 & Modern age & Central America & Writing & Species-document \\
\hline PROHENS ET AL 1996 & Modern age & Central America & Writing & Species-document \\
\hline $\begin{array}{l}\text { RAGHAVAN and BARUAH } \\
1958\end{array}$ & Antiquity & Asia & Writing & Species-document \\
\hline RAGONE ET AL 2001 & Modern age & Asia & Writing & Document-species \\
\hline RAMON-LACA 2003 & Modern age & Europe & Writing & Species-document \\
\hline RAZA 2006 & Antiquity & Africa; South America & Writing & Theme-documents \\
\hline RIVERA ET AL 1994 & Antiquity & Africa; Asia; Europe & Writing & Species-document \\
\hline RUSSO 1998 & Contemporary age & $\begin{array}{l}\text { North America; Asia; } \\
\text { Europe }\end{array}$ & Writing & Species-document \\
\hline SALICK ET AL 2006 & Contemporary age & Asia & Writing & $\begin{array}{l}\text { Theme-document- } \\
\text { species }\end{array}$ \\
\hline SMITH E PERINO 1981 & Contemporary age & North America & Writing & Species-documents \\
\hline SMITH ET AL 2003 & Contemporary age & Oceania & Writing & Theme-documents \\
\hline SPENCER 1984 & Modern age & North America & Writing & Species-documents \\
\hline $\begin{array}{l}\text { STÅHLBERG and } \\
\text { SVANBERG } 2010\end{array}$ & Modern age & Asia & Writing & Document-species \\
\hline SWENSON ET AL 1997 & Modern age & South America & Writing & $\begin{array}{l}\text { Theme-document- } \\
\text { species }\end{array}$ \\
\hline TICKTIN 2002 & Modern age & Central America & Writing & Species-documents \\
\hline
\end{tabular}




\begin{tabular}{|c|c|c|c|c|}
\hline REFERENCES & $\begin{array}{c}\text { AGE OF } \\
\text { DOCUMENT }\end{array}$ & $\begin{array}{l}\text { PLACE OF DOCUMENT } \\
\text { ORIGIN }\end{array}$ & $\begin{array}{l}\text { NATURE OFTHE } \\
\text { SOURCE }\end{array}$ & SEARCH PATH \\
\hline WEIL 1965 & Timeframe unclear & $\begin{array}{l}\text { Africa; North America; } \\
\text { South America; Asia; } \\
\text { Europe }\end{array}$ & Writing & Species-documents \\
\hline WIDRLECHNER 1981 & Antiquity & Africa; Asia; Europe & Writing & Species-documents \\
\hline WYK 2008 & Timeframe unclear & Africa & Writing & $\begin{array}{l}\text { Theme-document- } \\
\text { species }\end{array}$ \\
\hline YESILADA 2005 & Timeframe unclear & Asia & Writing & $\begin{array}{l}\text { Theme-document- } \\
\text { species }\end{array}$ \\
\hline YONOS ET AL 2005 & Timeframe unclear & Asia & Writing & Species-documents \\
\hline ZÁRATE 1997 & Modern age & Central America & Writing & Species-documents \\
\hline ZEPEDA and WHITE 2008 & Modern age & Central America & $\begin{array}{l}\text { Writing; } \\
\text { Iconographic }\end{array}$ & $\begin{array}{l}\text { Document-species; } \\
\text { others }\end{array}$ \\
\hline $\begin{array}{l}\text { ZEVEN and } \\
\text { BRANDENBURG } 1986\end{array}$ & Modern age & Europe & Iconographic & $\begin{array}{l}\text { Theme-document- } \\
\text { species }\end{array}$ \\
\hline
\end{tabular}

Most studies $(40.0 \%)$ reflected a contrast between the historical records and the current status of plant cultivation or usage, either by direct comparison (Zepeda and White 2008; Leonti et al. 2010) or by evaluating the historical evolution of human relationships with the specific plant resources addressed (Bedigian 2004; Aderkas 1984; Buckles 1995). Regarding the types of use discussed in the publications, the medical category predominated in $54 \%$ of all of the works that were assessed. This pattern is also found in conventional ethnobotanical studies and reflects a growing interest among researchers to investigate this usage category (Oliveira et al 2009). However, both recent documents and old manuscripts generally contain a greater degree of medicinal usagerelated detail; thus, the interest in these sources is not simply restricted to modern researchers but extends to historical naturalists. The use of plants for food purposes was addressed in $46 \%$ of the studies, whereas the "Other" categories of plant usage were present in less than $6.5 \%$ of all the studies that were assessed (Table 3 ).

Table 3.The use categories and their frequency of occurrence in 103 publications related to historical ethnobotany.

\begin{tabular}{cc}
\hline Use categorY & Publication frequency (\%) \\
\hline Medical & 54 \\
Food & 46 \\
General & 12.5 \\
Ornamental & 6.5 \\
Spice & 5 \\
Fibres & 3.2 \\
Wood & 3.2 \\
Magic & 3.2 \\
Aromatic & 2.2 \\
Forage & 2.2 \\
Technological & 2.2 \\
Poison & 2,2 \\
Hallucinogen & 1.1 \\
Fuel & 1.1 \\
\hline
\end{tabular}




\section{FINAL CONSIDERATIONS}

The present study has highlighted specific key features of historical ethnobotanical studies. However it should be considered that some information diluted or deleted in articles hampered the search and analysis of information. One of the difficulties hampering the analysis of these works was the clarification of the temporal framework; for example, some authors accessed historical documents but did not indicate the period in which these sources were generated. Notably, archaeological and paleobotanical data were frequently convoluted with written and iconographic records, without a clear correspondence between the information and sources; for example, in some cases, the studies showed results without reference to the type of source used, that is, written, iconographic or archaeological.

Two other aspects may result in the analytical difficulty that is associated with the primary sources used in these works. The first aspect relates to where the works were deposited, particularly when authors do not emphasise or specify the place where the documents were found. This information is important because it allows other researchers who intend to perform similar studies to know exactly where to locate the documents that were mentioned. The second aspect relates to the access level of the documents used in the analyses; in some cases, it is unclear whether the authors used an original source, a transcript or works that analysed or interpreted an original source. As an example, this was the case for a work that cited the use of plants during the colonial period, although the authors did not clearly reference the document they accessed to generate their findings.

Finally, our study revealed the vast scope of historical ethnobotanical studies, both in relation to geographical areas of study and to the diversity of approaches, demonstrating the interest of many researchers in this subject. This finding is important because, through these investigations, one can better understand the past relationships between people and plants and also contribute to the understanding of the current state and future of these relationships. Therefore, we believe that this scientific field exhibits great potential for development, and its findings continue to impact the importance of current ethnobotanical debates.

\section{ACKNOWLEDGEMENTS}

We would like to thank the Coordenação de Aperfeiçoamento de Pessoal de Nível Superior (Capes) for the PhD scholarship granted to Taline Cristina da Silva, the CNPq for the Masters scholarship granted to Alejandro Lozano Balcázar and the postdoctoral fellowship awarded to Maria Franco Trindade Medeiros, the Fundação de Amparo à Ciência e Tecnologia de Pernambuco (Facepe) for the PhD scholarship granted to Thiago Antonio de Sousa Araújo and the Instituto de Botánica del Nordeste UNNE-CONICET (Corrientes -Argentina) for the PhD scholarship granted to Analia Pirondo.

\section{REFERENCES}

1. Abrams MD, Nowacki GJ (2008) Native Americans as active and passive promoters of mast and fruit trees in the Eastern USA. The Holocene 7: 1123-1137.

2. Aderkas P (1984) Economic History of Ostrich Fern, Matteuccia struthiopteris, The Edible Fiddlehead. Economic Botany 1:14-23.

3. Albuquerque UP (1997) Etnobotânica: uma aproximação teórica e epistemológica. Revista Brasileira de Farmácia 3: 60-64.

4. Alencar NA, Medeiros PM, Medeiros MFT (2010) Medicinal Plants Prescribed in the Hospital of the São Bento Monastery between 1823 and 1824 in Olinda - Northeastern Brazil. The Open Complementary Medicine Journal 2:74-79.

5. Argounova-Low T (2009) Black Food: Subsistence, Diet, and Exchange in Yessei Yakut Society. Ethnohistory 3:479-507.

6. Austin DF (2007) Merremia dissecta (Convolvulaceae): Condiment, Medicine, Ornamental, and Weed - A Review. Economic Botany 2: 109-120.

7. Austin DF (2008) Evolvulus alsinoides (Convolvulaceae): An American herb in the Old World. Journal of Ethnopharmacology 117: $185-198$.

8. Austin DF, Felger RS (2008) Sichuan Peppers and the Etymology of Fagara (Rutaceae). Economic Botany 4:567-573.

9. Barbera G, Carimi F, Inglese P (1992) Past and present role of the Indian-fig prickly-pear (Opuntia ficus-indica (I.) miller, Cactaceae) in the agriculture of Sicily. Economic Botany 1: 1020.

10. Bedigian D (2004) History and lore of sesame in Southwest Asia. Economic Botany 3: 329-353.

11. Brandão MGL, Zanetti NNS, Oliveira P, Grael CFF, Santos ACP, Monte-Mór LMR (2008) Brazilian medicinal plants described 
by 19th century European naturalists and in the Official Pharmacopoeia. Journal of Ethnopharmacology 120: 141-148.

12. Brandão MGL, Cosenza GP, Grael CFF, Netto Junior NL, MonteMór RLM (2009) Traditional uses of American plant species from the 1st edition of Brazilian Official Pharmacopoeia. Revista Brasileira de Farmacognosia 19: 478-487.

13. Brendler T, Van Wyk BE (2008) A historical, scientific and commercial perspective on the medicinal use of Pelargonium sidoides (Geraniaceae). Journal of Ethnopharmacology 119: 420-433.

14. Buckles D (1995) A "New" Plant With a History. Economic Botany 1: 13-25.

15. Burns WR (2008) East meets West: how China almost cured malaria. Endeavour 3: 101-106.

16. Burton RA, Cox PA (1998) Culture and Mormon Economic Development in the Intermountain West. Economic Botany 2:201206.

17. Bussmann RW, Sharon D (2009) Shadows of the colonial past - diverging plant use in Northern Peru and Southern Ecuador. Journal of Ethnobiology and Ethnomedicine 4:1-17.

18. Chadwick Cl, Lumpkin TA, Elberson LR (1993) The Botany, Uses and Production of Wasabia japonica (Miq.) (Cruciferae) Matsum. Economic Botany 2:113-135.

19. Charney WR, Basbous M (1978) The cedards of Lebanon Witness of history. Economic Botany 32: 118-123.

20. Collins JL (1949) History, Taxonomy and Culture of the Pineapple. Economic Botany 1:335-359.

21. Correll DS (1953) Vanilla - Its Botany, History, Cultivation and Economic Import. Economic Botany 1:291-358.

22. Dafni A, Levy S, Lev E (2005) The ethnobotany of Christ's Thorn Jujube (Ziziphus spina-christi) in Israel. Journal of Ethnobiology and Ethnomedicine 1: 1-11.

23. Dalton $S$, Charnigo $C$ (2004) Historians and their information sources. College and Research Libraries 401:400-425.

24. De Natale A, Pezzatti GB, Pollio A (2009) Extending the temporal context of ethnobotanical databases: the case study of the Campania region (southern Italy). Journal of Ethnobiology and Ethnomedicine 7:1-18.

25. Delyser DY, Kaspe WJ (1994) Hopped Beer: The Case for Cultivation. Economic Botany 2: 166-170.

26. Dove MR (1997) The "Banana Tree at the Gate": Perceptions of Production of Piper nigrum (Piperaceae) in a Seventeenth Century Malay State. Economic Botany 4:347-361.

27. Edwardson JR (1952) Hops-Their Botany, History, Production and Utilization. Economic Botany 2:360-375.

28. Erwin AT (1950) The Orion and History of Pop Corn. Economic Botany 3:294-299.

29. Ford RI (1979) Paleoethnobotany in American archaeology. Advances in Archaeological Method and Theory 2:285-336.

30. Fulling EH (1953) American Witch Hazel-History, Nomenclature and Modern Utilization. Economic Botany 4:359-381

31. Gentry HS (1958) The Natural History of Jojoba (Simmondsia chinensis) and Its Cultural Aspects. Economic Botany 1:261-295.

32. Giorgettim NG, Rodrigues E (2007) Brazilian plants with possible action on the central nervous system-Astudy of historical sources from the 16th to 19th Century. Journal of Ethnopharmacology 109:338-347
33. Goor A (1965) The History of the Fig in the Holy Land from Ancient Times to the Present Day. Economic Botany 1:124-135.

34. Goor A (1966a) The Place of the Olive in the Holy Land and its History Through the Ages. Economic Botany 2:223-243.

35. Goor A (1966b) The History of the Grape Vine in the Holy Land. Economic Botany 1:46-64.

36. Goor A (1967a) The History of the Date through the Ages in the Holy Land. Economic Botany 21:320-340.

37. Goor A (1967b) The History of the Pomegranate in the Holy Land. Economic Botany 3:215-230.

38. Guarino C, Casoria P, Menale B (2000) Cultivation and use of Isatis tinctoria L. (Brassicaceae) in Southern Italy. Economic Botany 3:395-400.

39. Haller Jr JS (1990) A drug for all seasons medical and pharmacological history of Aloe. Bulletin of the New York Academy of Medicine 6:647-659.

40. Heinrich M, Kufer J, Leonti M, Pardo-de-Santayana M (2006) Ethnobotany and ethnopharmacology - Interdisciplinary links with the historical sciences. Journal of Ethnopharmacology 107 : 157-160.

41. Hernandes J, Garcia F (1998) An end-point method for estimation of the total antioxidant activity in plant material. Phytochemical Analysis 9:196-202.

42. Hsu $E$ (2006) The history of qing hao in the Chinese Materia Medica. Transactions of the Royal Society of Tropical Medicine and Hygiene 100: 505-508.

43. Hu SY (1967) The Economic Botany of Dragon Tongue. Economic Botany 12:288-292.

44. Hymowitz T, Harlan JR (1983). Introduction of Soybean to North America by Samuel Bowen in 1765. Economic Botany 4:371-379.

45. Joubert E, Gelderblom WCA, Louwd A (2008) South African herbal teas: Aspalathus linearis, Cyclopia spp. and Athrixia phylicoides-A review. Journal of Ethnopharmacology 119:376412.

46. Kingsbury JM (1961) Knowledge of Poisonous Plants in the United States - Brief History and Conclusion. Economic Botany 15: $119-130$

47. Kitagawa J, Nakagawa T, Okuda M, Fukuoka M, Yasud Y (2008) Correcting Misperceptions about the History of Castanea Stands in Satoyama in Japan. Economic Botany 4: 594-603.

48. Krochmal A, Grierson W (1961) Brief History of Grape Growing in the United States. Economic Botany 15: 114-118.

49. Leal F, Amaya L (1991) The curagua (Ananas lucidus, Bromeliaceae) Crop in Venezuela. Economic Botany 2: 216-224.

50. Leonti CL, Sanna F, Bonsignore L (2009) A comparison of medicinal plant use in Sardinia and Sicily - De Materia Medica revisited? Journal of Ethnopharmacology 121: 255-267.

51. Leonti M, Cabras S, Weckerle CS, Solinasa MN, Casu L (2010) The causal dependence of present plant knowledge on herbalsContemporary medicinal plant use in Campania (Italy) compared to Matthioli (1568). Journal of Ethnopharmacology 130:379-391.

52. Locher C, Currie L (2010) Revisiting kinos-An Australian perspective. Journal of Ethnopharmacology 128: 259-267.

53. Luczaj L (2008) Archival data on wild food plants used in Poland in 1948. Journal of Ethnobiology and Ethnomedicine 4: 1-19. 
54. Luczaj L (2009a) Bladdernut (Staphylea pinnata L.) in Polish folklore. Rocznik Polskiego Towarzystwa Dendrologicznego 57: 23-28.

55. Luczaj L (2009b) Primroses versus Spruces: Cultural differences between flora depicted in British and Polish children's books. Ethnobotany Research \& Applications 7: 115-121.

56. Luczaj L (2010a) Changes in Assumption Day Herbal Bouquets in Poland: A Nineteenth Century Study Revisited. Economic Botany 65: 66-75.

57. Luczaj $L(2010 \mathrm{~b})$ Changes in the utilization of wild green vegetables in Poland since the 19th century: A comparison of four ethnobotanical surveys. Journal of Ethnopharmacology 128:395-404.

58. Luczaj L (2010c) Plant identification credibility in ethnobotany: a closer look at Polish ethnographic studies. Journal of Ethnobiology and Ethnomedicine 6: 1-16.

59. Luczaj L (2012) A relic of medieval folklore: Corpus Christi Octave herbal wreaths in Poland and their relationship with the local pharmacopoeia. Journal of Ethnopharmacology 142: 228-240.

60. Luczaj L, Dumanowski J, Köhler P, Mueller-Bieniek A (2012) The Use and Economic Value of Manna grass (Glyceria) in Poland from the Middle Ages to the Twentieth Century. Human Ecology 40: $720-733$.

61. Martin RT (1970) The Role of Coca in the History, Religion, and Medicine of South American Indians. Economic Botany 24: 422438.

62. Medeiros MFT (2009) Etnobotânica histórica: princípios e procedimentos. NUPEEA, Recife

63. Medeiros MFT, Senna-Valle L, Andreata RHP (2007) Histórico e o uso da "salsa parilha" (Smilax spp.) pelos boticários no Mosteiro de São Bento. Revista Brasileira de Biociências 1: 2729.

64. Medeiros MFT, Andreata RHP, Valle LS (2010) Identificação de termos oitocentistas relacionados às plantas medicinais usadas no Mosteiro de São Bento do Rio de Janeiro, Brasil. Acta Botânica Brasilica 3: 780-789.

65. Merlin MD (2000) A History of Ethnobotany in Remote Oceania. Pacific Science 3: 275-287.

66. Monachino J (1954) Rauvolfia serpentina - Its History, Botany and Medical Use. Economic Botany 8: 349- 365.

67. Moolla A, Viljoen AM (2008) 'Buchu' - Agathosma betulina and Agathosma crenulata (Rutaceae): A review. Journal of Ethnopharmacology 119:413-419.

68. Müller JG, Ogneva-Himmelberger Y, Lloyd S, Reed JM (2010) Predicting Prehistoric Taro (Colocasia esculenta var. antiquorum) Lo'i Distribution in Hawaii. Economic Botany 1: 22-33.

69. Negbi MA (1992) Sweetmeat Plant, a Perfume Plant and Their Weedy Relatives: A Chapter in the History of Cyperus esculentus L. and C. rotundus L. Economic Botany 1: 64-71.

70. Nicholson GE (1958) The Production, History, Uses and Relationships of Cotton (Gossypium spp.) In Ethiopia. Economic Botany 14: 3-36.

71. Norton HH (1979) Evidence for Bracken Fern as a Food for Aboriginal Peoples of Western Washington. Economic Botany 4: 384-396.

72. Norton HH (1981) Plant Use in Kaigani Haida Culture: Correction of an Ethnohistorical Oversight. Economic Botany 4: 434-449.
73. Oliveira FC, Albuquerque UP, Fonseca-Kruel VS, Hanazaki N (2009) Avanços nas pesquisas etnobotânicas no Brasil. Acta Botanica Brasilica 23: 580-605.

74. Oudijk $M$, Jansen $M(2000)$ Changing History in the Lienzos de Guevea and Santo Domingo Petapa. Ethnohistory 2: 281-331.

75. Palmer $R$ (1985) Medical botany in northern Italy in the Renaissance. Journal of the Royal Society of Medicine 78: 149157.

76. Pardo-de-Santayana M, Tardío J, Heinrich M, Touwaide A, Morales R (2006) Plants in the Works of Cervantes. Economic Botany 2: 159-181.

77. Polata R, Satı F (2012) An ethnobotanical survey of medicinal plants in Edremit Gulf (Balıkesir - Turkey). Journal of Ethnopharmacology 139: 226-241.

78. Pollio A, De Natale A, Appetiti E, Aliotta G, Touwaide A (2008) Continuity and change in the Mediterranean medical tradition: Ruta spp. (rutaceae) in Hippocratic medicine and present practices. Journal of Ethnopharmacology 116: 469-482.

79. Porterfield WM (2008) Loofah-The Sponge Gourd. Economic Botany 9: 211-223.

80. Prohens J, Ruiz JJ, Nuez F (1996) The Pepino (Solanum muricatum, Solanaceae): A “New" Crop With a History. Economic Botany 4: 355-368.

81. Raghavan V, Baruah HK (1958) Arecanut: India's Popular Masticatory History, Chemistry and Utilization. Economic Botany 12: $315-345$

82. Ragone D, Lorence DH, Flynn T (2001) History of plant introductions to Pohnpei, Micronesia and the role of the Pohnpei agriculture station. Economic Botany 2: 290-324.

83. Rai R (2010) Themes in world history. Prince Print, New Dehli.

84. Ramon-Laca L (2003) Trie Introduction of Cultivated Citrus Northern Africa and the Iberian Peninsula. Economic Botany 4: 502-514.

85. Raza M (2006) A role for physicians in ethnopharmacology and drug discovery. Journal of Ethnopharmacology 104: 297-301.

86. Rivera D, Obon C, Cano F (1994) The Botany, History and Traditional Uses of Three-Lobed Sage (Salvia fruticosa Miller) (Labiatae). Economic Botany 2: 190-195.

87. Russo $E$ (1998). Cannabis for migraine treatment: the once and future prescription? An historical and scientific review. Pain 76:3-8.

88. Salick J, Byg A, Amend A, Gunn B, Law W, Schmidt H (2006) Tibetan Medicine Plurality. Economic Botany 3: 227-253.

89. Smith JL, Perino JV (1981) Osage Orange (Maclura pomifera): History and Economic Uses. Economic Botany 1: 24-41.

90. Smith TB, Hviding E, Whitmore T (2003) Rainforest Composition and Histories of Human Disturbance in Solomon Islands. Ambio 5: 346-352.

91. Spencer NR (1984) Velvetleaf, Abutilon theophrasti (Malvaceae), History and Economic Impact in the United States. Economic Botany 4: 407-416.

92. Ståhlberg S, Svanberg I (2010) Gathering Food From Rodent Nests in Siberia. Journal of Ethnobiology 30: 184-202.

93. Swenson U, Stuessy TF, Baeza M, Crawford DJ (1997) New and Historical Plant Introductions, and Potential Pests in the Juan Fernandez Islands, Chile. Pacific Science 3: 233-253. 
94. Terraciano K (2010) Three texts in one: Book XII of the Florentine Codex. Ethnohistory 4: 53-57.

95. Ticktin T (2002) The History of Ixtle in Mexico. Economic Botany 56: 92-94.

96. Weill AT (1965) Nutmeg as a Narcotic. Economic Botany 19:194217.

97. Widrlechner MP (1981) History and Utilization of Rosa damascena. Economic Botany 1: 42-58.

98. Wyk BE (2008) A review of Khoi-San and Cape Dutch medical ethnobotany. Journal of Ethnopharmacology 119: 331-341.

99. Yesilada E (2005) Past and future contributions to traditional medicine in the health care system of the Middle-East. Journal of Ethnopharmacology 100: 135-137.

100. Yonos C, Soulimani R, Seddiqi N, Baburi O, Dicko A (2005) Étude ethnobotanique et historique des tamaris (Tamarix sp., Tamaricaceae) et leurs usages actuels en Afghanistan. Phytothérapie 6: 248-251.

101. Zárate S (1997) Domestication of cultivated Leucaena (Leguminosae) in Mexico: the Sixteenth Century documents. Economic Botany 51: 238- 250.

102. Zepeda CG, White LO (2008) Herbolaria y pintura mural: Plantas medicinales en los murales del Convento del Divino Salvador de Malinalco, Estado de México. Polibotânica 25: 173-199.

103. Zeven AC, Brandenburg WA (1986) Use of Paintings from the 16th to 19th Centuries to Study the History of Domesticated Plants. Economic Botany 4: 397-408. 